\title{
PENGARUH PENERAPAN MODEL PEMBELAJARAN KOOPERATIF TIPE STAD DIPADUKAN DENGAN STRATEGI INKUIRI TERBIMBING TERHADAP AKTIVITAS DAN HASIL BELAJAR MAHASISWA
}

\author{
Moh. Mulyadi Prasetyo \\ Sekolah Tinggi Keguruan dan Ilmu Pendidikan Pembangunan Indonesia \\ E-mail : mulhands@gmail.com
}

\begin{abstract}
Abstrak
Penelitian ini bertujuan untuk mengetahui: (1) aktivitas mahasiswa yang diajar dengan penerapan model pembelajaran kooperatif tipe STAD yang dipadu strategi inkuiri terbimbing, (2) hasil belajar siswa yang diajar dengan penerapan model pembelajaran kooperatif tipe STAD yang dipadu strategi inkuiri terbimbing, (3) pengaruh penerapan model pembelajaran kooperatif tipe STAD yang dipadu strategi inkuiri terbimbing terhadap hasil belajar mahasiswa dan (4) pengaruh model pembelajaran kooperatif tipe STAD yang dipadu strategi inkuiri terbimbing terhadap hasil belajar siswa melalui aktivitas siswa. Jenis Penelitian ini adalah penelitian eksperimen semu (quasi experiment). Teknik pengumpulan data menggunakan lembar observasi aktivitas mahasiswa dan tes hasil belajar. Hasil penelitian menunjukkan bahwa (1) aktivitas mahasiswa berada pada kategori sangat aktif; (2) hasil belajar berada pada kategori tinggi; (3) penerapan model pembelajaran kooperatif tipe $S T A D$ yang dipadu strategi inkuiri terbimbing berpengaruh secara signifikan terhadap hasil belajar siswa dan (4) penerapan model pembelajaran kooperatif tipe STAD yang dipadu strategi inkuiri terbimbing berpengaruh tidak langsung terhadap hasil belajar melalui aktivitas mahasiswa.
\end{abstract}

Kata kunci: kooperatif tipe $S T A D$, inkuiri terbimbing, aktivitas, hasil belajar

\begin{abstract}
The study aims to examining: (1) students' activity taught by implementing cooperative learning model of STAD type integrated with guided inquiry strategy, (2) learning outcomes of students taught by implementing cooperative learning model of STAD type integrated with guided inquiry strategy, (3) the influence of the implementing of cooperative learning model of STAD type integrated with guided inquiry strategy on learning outcomes of students and (4) the influence of cooperative learning model of STAD type integrated with guided inquiry strategy on learning outcomes of students through student's activity. The study is a quasi experiment research. Data were collected using observation sheets of students' activity and test of learning outcomes. The results of study reveal that (1) students' activity is in extremely active category, (2) learning outcomes is in high category, (3) the implementation of cooperative learning model of STAD type integrated with guided inquiry strategy gives significant influence toward learning outcomes of students, and (4) the implementation of cooperative learning model of STAD type integrated with guided inquiry strategy gives indirect influence toward learning outcomes through student's activity.
\end{abstract}

Keywords: cooperative of STAD type, guided inquiry, activity, learning outcomes 
Jurnal Binomial Vol. 3 No. 2 September 2020

\section{PENDAHULUAN}

Program studi ilmu pendidikan diharapkan mampu menghasilkan lulusan yang memiliki pengetahuan dan keahlian praktis di bidang pendidikan. Berdasarkan keperluan ini, maka dibutuhkan suatu satuan proses belajar dan mengajar yang mampu mengakomodasi serta mengintegrasikan ilmu dan praktek demi tercapainya harapan tersebut. Kegiatan pembelajaran sebenarnya dilakukan sebagai upaya untuk memberikan pengalaman nyata kepada mahasiswa dalam mengimplementasikan kajian teori dan untuk membuktikan teori-teori yang telah ada dengan tujuan menjadikan praktik belajar sebagai bagian yang integral dalam ilmu pengetahuan alam.

Pendidikan merupakan salah satu sektor penting dalam menghasilkan sumber daya manusia yang mampu bersaing dan berkompetisi terutama di era globalisasi dan informasi sekarang ini. Melalui pendidikan manusia dapat mengembangkan potensi dan membangun kepribadian yang baik dalam dirinya. Oleh karena itu, diperlukan pembenahan kualitas dibidang pendidikan. Upaya untuk meningkatkan kualitas pendidikan, tidak lepas dari peranan dosen yang memberikan keteladanan, membangun kemauan dan mengembangkan potensi serta kreatifitas mahasiswa.

Masalah yang berkembang dalam pembelajaran adalah kurang diterapkannya pembelajaran aktif (active learning). Proses belajar mengajar yang terjadi saat ini masih didominasi oleh dosen (pembelajaran berorientasi teacher-centered), sementara siswa relatif pasif menerima dan mengikuti apa yang disajikan. Oleh sebab itu, dosen sebagai pendidik harus selalu memilih model dan strategi pembelajaran yang tepat, yang dipandang lebih efektif sehingga dapat membantu siswa memahami materi dan meningkatkan hasil belajar. Pemilihan strategi maupun model pembelajaran yang akan digunakan dalam proses pembelajaran harus berorientasi pada tujuan pembelajaran yang akan dicapai, harus disesuaikan dengan materi, karakteristik mahasiswa serta kondisi berlangsungnya proses pembelajaran.

Berdasarkan observasi awal pada mahasiswa STKIP PI melalui wawancara dengan dosen lainnya, bahwa dalam proses belajar mengajarnya aktivitas mahasiswa masih kurang. Hal ini tampak dengan kurangnya aktivitas mahasiswa 
Jurnal Binomial Vol. 3 No. 2 September 2020

dalam mengajukan pertanyaan, mengemukakan idenya dan membuat gagasan sendiri. Selain itu, data yang diperoleh peneliti mengenai hasil belajar Biologi mahasiswa belum memadai berdasarkan Kriteria Ketuntasan Minimal (KKM) yang telah ditetapkan, yaitu 75 . Persentase mahasiswa yang mencapai KKM hanya mencapai $42 \%$. Indikatorindikator tersebut mengisyaratkan bahwa ada yang perlu dibenahi dalam proses pembelajaran yang berlangsung selama ini khususnya strategi maupun model pembelajaran.

Sehubungan dengan uraian di atas, untuk mengatasi masalah yang telah dikemukakan sebelumnya, solusi alternatif untuk melakukan pembelajaran inovatif yang dapat meningkatkan mutu pendidikan khususnya dalam pembelajaran Biologi adalah model pembelajaran kooperatif tipe STAD yang dipadu strategi inkuiri terbimbing. Model pembelajaran ini memadukan sintaks pembelajaran kooperatif tipe STAD dengan pembelajaran inkuiri terbimbing. Pertimbangan memadukan sintaks pembelajaran kooperatif tipe STAD dengan pembelajaran inkuiri terbimbing, didasari karakteristik model dan strategi pembelajaran tersebut.
Karakteristik

pembelajaran kooperatif, menuntut mahasiswa mampu saling belajar satu sama lain melalui kegiatan diskusi. Dalam pembelajaran kooperatif, mahasiswa bekerjasama dalam kelompok kecil yang heterogen dari segi prestasi, jenis kelamin, dan suku untuk saling membantu dalam tujuan bersama. Dalam kelas kooperatif mahasiswa diharapkan saling berdiskusi dan berargumentasi untuk menguasai pengetahuan yang mereka kuasai saat itu sehingga terjadi interaksi antar mahasiswa atau antar mahasiswa dan dosen, yang menunjukkan adanya aktivitas belajar (Slavin, 2009).

Alasan dipilihnya model pembelajaran kooperatif tipe STAD karena memiliki kelebihan antara lain merupakan metode yang sederhana yang mudah digunakan di dalam kelas, mempersiapkan mahasiswa untuk belajar, dan dapat melatih mahasiswa untuk bekerjasama (Rustam, 2010). Akan tetapi, kelemahan pembelajaran kooperatif tipe STAD adalah kemampuan kerja individual mahasiswa kurang maksimal sehingga untuk mencegah hal tersebut dapat digunakan strategi inkuiri terbimbing. 
Jurnal Binomial Vol. 3 No. 2 September 2020

Karakteristik pembelajaran inkuiri terdiri atas identifikasi struktur terbimbing, memberikan kesempatan mikroskopis beserta fungsinya, proses kepada mahasiswa untuk mempelajari fisiologis tubuh yang berkaitan dengan cara menemukan fakta, konsep dan struktur dan fungsinya, serta hubungan prinsip melalui pengalamannya secara langsung. Jadi, mahasiswa bukan hanya belajar dengan membaca kemudian menghafal materi pelajarannya, tetapi juga mendapatkan kesempatan untuk berlatih mengembangkan keterampilan berpikir dan bersikap ilmiah sehingga memungkinkan terjadinya proses konstruksi pengetahuan dengan baik sehingga mahasiswa dapat meningkatkan pemahamannya pada materi yang dipelajari (Budiada, 2011). Lebih jauh Ambarsari (2013) mengungkapkan bahwa pembelajaran inkuiri terbimbing memberikan kesempatan untuk berpikir mandiri dan saling membantu dengan teman yang lain, sehingga mahasiswa memiliki tanggung jawab individu dan tanggung jawab dalam kelompok.

Pembelajaran tersebut diterapkan pada sub materi pokok Sistem Pernapasan. Beberapa pertimbangan yang mendasari yaitu karena materi Sistem Pernapasan terdiri atas konsepkonsep yang yang cukup sulit untuk dipahami oleh mahasiswa. Hal ini dikarenakan konsep sistem pernapasan antar organ dalam kaitannya dengan sistem fisiologis tubuh. Selain itu, materi Sistem Pernapasan memiliki konsepkonsep yang cukup kompleks, sehingga diperlukan percobaan (eksperimen), pengamatan-pengamatan yang dilakukan untuk memberikan pemahaman yang cukup tentang teori dan konsep yang terkandung dalam materi tersebut dan dalam hubungannya dengan kehidupan kita sehari-hari.

Berdasarkan karakterisitik tersebut, maka materi Sistem Pernapasan dianggap cocok dengan model pembelajaran kooperatif tipe STAD yang dipadu strategi inkuiri terbimbing karena dapat meningkatkan aktivitas mahasiswa. Aktivitas-aktivitas seperti mengajukan pertanyaan, menduga jawabannya, merancang penyelidikan, melakukan eksperimen, mengelolah data, mengevaluasi hasil dan mengkomunikasikan temuannya kepada orang lain, memberikan kesempatan kepada siswa untuk aktif selama proses pembelajaran, sehingga hasil belajar mencapai hasil yang maksimal. 
Jurnal Binomial Vol. 3 No. 2 September 2020

Penerapan model pembelajaran mahasiswa STKIP Pembangunan kooperatif tipe STAD dipadukan strategi Indonesia yang diajar dengan model inkuiri terbimbing bertujuan agar seluruh pembelajaran kooperatif tipe STAD yang mahasiswa selalu aktif secara mental maupun fisik. Para siswa akan berperan aktif secara berkelompok melatih keberanian, berkomunikasi dan berusaha untuk memecahkan masalah, sehingga diharapkan memberikan nilai tambah terhadap peningkatan aktivitas dan hasil belajar mahasiswa khususnya pada pembelajaran Biologi.

Astrawan (2013) melaporkan bahwa model kooperatif tipe STAD meningkatkan hasil belajar. Penelitian yang dilakukan Dewi (2013) menyatakan pembelajaran inkuiri terbimbing meningkatkan hasil belajar mahasiswa. Begitu pula penelitian Afiah (2010) mengungkapkan bahwa melalui model kooperatif dengan metode inkuiri terbimbing dapat meningkatkan aktivitas dan hasil belajar hingga mencapai angka 90. Hasil tersebut sejalan dengan hasil penelitian Nurhidayati (2012), bahwa terdapat pengaruh metode integrasi STAD-inkuiri terbimbing terhadap aktivitas dan hasil belajar Biologi mahasiswa.

Tujuan penelitian yang ingin dicapai yaitu 1) Untuk mengetahui aktivitas

\section{METODE PENELITIAN}

Jenis penelitian adalah jenis eksperimen semu (quasi experiment) dengan rancangan pretest-posttest Only control group design. Penelitian dilaksanakan di STKIP Pembangunan Indonesia. Populasi penelitian adalah seluruh mahasiswa STKIP PI dan 
Jurnal Binomial Vol. 3 No. 2 September 2020

dilakukan pemilihan sampel secara random class dan kelas yang terpilih adalah IV C sebagai kelas eksperimen dan IV B sebagai kelas kontrol masingmasing berjumlah 24 orang. Teknik pengumpulan data dilakukan lembar observasi aktivitas mahasiswa dan tes hasil belajar. Instrumen yang digunakan berupa lembar observasi untuk melihat aktivitas mahasiswa dan tes hasil belajar. Data yang diperoleh dianalisis secara deskriptif dengan menggunakan normalisasi gain dan analisis inferensial melalui uji anacova dan analisis jalur (Path Analysis).

\section{HASIL DAN PEMBAHASAN}

\section{Deskripsi Hasil Analisis Data}

1. Deskripsi Aktivitas mahasiswa

Data hasil observasi aktivitas mahasiswa yang diperoleh dengan menggunakan lembar observasi selama proses pembelajaran kooperatif tipe STAD yang dipadu strategi inkuiri terbimbing, dapat dilihat pada Tabel 1.

Tabel 1. Aktivitas mahasiswa pada Kelas Eksperimen

\begin{tabular}{lc}
\hline \multicolumn{1}{c}{ Indikator yang Diamati } & \% \\
\hline $\begin{array}{l}\text { Memperhatikan/mendengarkan } \\
\text { penjelasan dosen }\end{array}$ & 94,85 \\
\hline
\end{tabular}

\begin{tabular}{lc}
\hline $\begin{array}{l}\text { Bertanya dan menjawab pertanyaan } \\
\text { dari dosen }\end{array}$ & 45,02 \\
\hline $\begin{array}{l}\text { Membentuk kelompok sesuai } \\
\text { arahan dosen }\end{array}$ & 97,62 \\
\hline $\begin{array}{l}\text { Membaca, memahami dan } \\
\text { mengidentifikasi rumusan }\end{array}$ & 85,71 \\
\hline Membuat hipotesis (jika ada) & 83,93 \\
\hline $\begin{array}{l}\text { Mengumpulkan data melalui kajian } \\
\text { pustaka atau praktikum }\end{array}$ & 80,95 \\
\hline $\begin{array}{l}\text { Berdiskusi dengan teman kelompok } \\
\text { untuk menyelesaikan LKS }\end{array}$ & 88,10 \\
\hline $\begin{array}{l}\text { Melakukan presentasi/memberikan } \\
\text { pertanyaan atau tanggapan }\end{array}$ & 35,12 \\
\hline Membuat kesimpulan & 88,10 \\
\hline $\begin{array}{l}\text { Merangkum materi yang telah } \\
\text { dipelajari }\end{array}$ & 85,71 \\
\hline
\end{tabular}

Berdasarkan Tabel 1, diperoleh informasi bahwa aktivitas yang paling banyak dilakukan oleh mahasiswa adalah membentuk kelompok sesuai arahan dosen dengan persentase 97,62\%, sedangkan aktivitas yang mendapat respon paling sedikit adalah melakukan presentasi yakni $35,12 \%$.

Data hasil observasi aktivitas mahasiswa selama proses pembelajaran kooperatif tipe STAD, dapat dilihat pada Tabel 2.

Tabel 2. Aktivitas mahasiswa pada Kelas Kontrol

\begin{tabular}{lc}
\hline \multicolumn{1}{c}{ Indikator yang Diamati } & $\mathbf{\%}$ \\
\hline $\begin{array}{l}\text { Memperhatikan/mendengarkan } \\
\text { penjelasan dosen }\end{array}$ & 91,76 \\
\hline Mencatat penjelasan dosen & 71,34 \\
\hline Menjawab pertanyaan dosen & 22,22 \\
\hline $\begin{array}{l}\text { Membentuk kelompok sesuai } \\
\text { arahan dosen }\end{array}$ & 89,29 \\
\hline
\end{tabular}


Jurnal Binomial Vol. 3 No. 2 September 2020

\begin{tabular}{lc}
\hline Melakukan kajian literatur & 70,83 \\
\hline $\begin{array}{l}\text { Bertanya tentang materi yang } \\
\text { kurang dimengerti }\end{array}$ & 26,19 \\
\hline $\begin{array}{l}\text { Berdiskusi dengan teman } \\
\text { kelompok untuk menyelesaikan }\end{array}$ & 58,93 \\
LKS & 26,19 \\
\hline $\begin{array}{l}\text { Melakukan } \\
\text { presentasi/memberikan } \\
\text { pertanyaan atau tanggapan }\end{array}$ & \\
\hline Membuat kesimpulan & 73,81 \\
\hline $\begin{array}{l}\text { Merangkum materi yang telah } \\
\text { dipelajari }\end{array}$ & 76,19 \\
\hline
\end{tabular}

Berdasarkan Tabel 2, diperoleh informasi bahwa aktivitas yang paling banyak dilakukan oleh mahasiswa adalah memperhatikan penjelasan dosen dengan persentase 91,67\%, sedangkan aktivitas yang mendapat respon paling sedikit adalah menjawab pertanyaan dosen yakni $22,22 \%$.

Distribusi frekuensi aktivitas mahasiswa pada kelas eksperimen maupun kelas kontrol dengan kategori sangat aktif, aktif, kurang aktif dan tidak aktif.

Pengkategorian aktivitas mahasiswa selama proses pembelajaran pada kelas eksperimen terlihat bahwa persentase yang sangat aktif sebanyak 51\%, aktif sebanyak $47 \%$, kurang aktif sebanyak $2 \%$ dan tidak aktif sebanyak 0\%. Akan tetapi, pada kelas kontrol terlihat bahwa persentase yang sangat aktif sebanyak $21 \%$, aktif sebanyak $60 \%$, kurang aktif sebanyak $18 \%$ dan tidak aktif sebanyak $2 \%$.

Deskripsi Hasil Belajar

Penilaian hasil belajar diukur dengan menggunakan tes pilihan ganda. Tes ini diberikan sebelum dan sesudah pembelajaran (pretest-posttest), baik pada kelas eksperimen yang diajarkan dengan penerapan model pembelajaran kooperatif tipe $S T A D$ yang dipadu strategi inkuiri terbimbing maupun pada kelas kontrol yang diajar tanpa strategi inkuiri terbimbing.

Data statistik hasil belajar materi

\begin{tabular}{lcc}
\hline \multirow{2}{*}{ Kategori } & \multicolumn{2}{c}{ Persentase (\%) } \\
\cline { 2 - 3 } & $\begin{array}{c}\text { Kelas } \\
\text { Eksperimen }\end{array}$ & $\begin{array}{c}\text { Kelas } \\
\text { Kontrol }\end{array}$ \\
\hline Sangat aktif & 3 & 4 \\
Aktif & 19 & 13 \\
Kurang & 1 & 5 \\
aktif & 1 & 2 \\
Tidak aktif & 24 & 24 \\
\hline Jumlah & & \\
sistem pernapasan mahasiswa STKIP PI \\
pada kelas eksperimen dan kelas kontrol \\
dapat dilihat pada Tabel 4. \\
Tabel 4 Statistik Deskriptif Hasil Belajar \\
mahasiswa STKIP PI
\end{tabular}

\begin{tabular}{lcc}
\hline \multirow{2}{*}{ Statistik } & \multicolumn{2}{c}{ Nilai } \\
\cline { 2 - 3 } & $\begin{array}{c}\text { Kelas } \\
\text { Eksperimen }\end{array}$ & $\begin{array}{c}\text { Kelas } \\
\text { Kontrol }\end{array}$ \\
\hline Subjek & 24,00 & 24,00 \\
Rata-rata & 80,60 & 75,43 \\
Median & 80,00 & 77,00
\end{tabular}


Jurnal Binomial Vol. 3 No. 2 September 2020

\begin{tabular}{lcc}
$\begin{array}{l}\text { Standar } \\
\text { deviasi }\end{array}$ & 0,98 & 1,26 \\
$\begin{array}{l}\text { Rentang } \\
\text { Nilai }\end{array}$ & 26,00 & 30,00 \\
$\begin{array}{l}\text { minimal } \\
\text { Nilai } \\
\text { maksimal }\end{array}$ & 67,00 & 60,00 \\
\hline
\end{tabular}

Tabel 4 menunjukkan bahwa ada perbedaan hasil belajar mahasiswa pada materi sistem pernapasan antara kelas eksperimen yang diajar dengan penerapan model pembelajaran kooperatif tipe STAD yang dipadu strategi inkuiri dan kelas kontrol yang diajar dengan penerapan model pembelajaran kooperatif tipe STAD. Hal ini terlihat dari nilai rata-rata hasil belajar kelas eksperimen adalah 80,60 sedangkan kelas kontrol adalah 75,43.

Data distribusi frekuensi dan kategori skor hasil belajar mahasiswa STKIP PI pada kelas eksperimen dan kelas kontrol terlihat pada Tabel 4.

Tabel 5 Hasil pengkategorian Hasil Belajar mahasiswa STKIP PI

\begin{tabular}{cllll}
\hline $\begin{array}{c}\text { Sangat } \\
\text { rendah }\end{array}$ & & & & \\
\hline Jumlah & 24 & 100 & 24 & 100 \\
\hline
\end{tabular}

Tabel 5, menunjukkan bahwa distribusi nilai hasil belajar mahasiswa terdapat pada kategori sangat tinggi dan tinggi. Data tersebut mengindikasikan adanya perbedaan hasil belajar, hal ini dapat dilihat dari nilai hasil belajar setelah pembelajaran.

Nilai hasil belajar setelah pembelajaran pada kelas eksperimen untuk kategori sangat tinggi sebanyak 7 orang $(28,57 \%)$ dan kategori tinggi sebanyak 17 orang $(71,43 \%)$. Pada kelas kontrol untuk kategori sangat tinggi sebanyak 2 orang (14,29\%), kategori tinggi sebanyak 21 orang $(73,81 \%)$ dan kategori cukup sebanyak 1 orang $(11,90 \%)$. Hasil ini mengindikasikan bahwa terdapat pengaruh pemberian perlakuan terhadap hasil belajar. Kelas yang diajar dengan penerapan model pembelajaran kooperatif tipe STAD yang

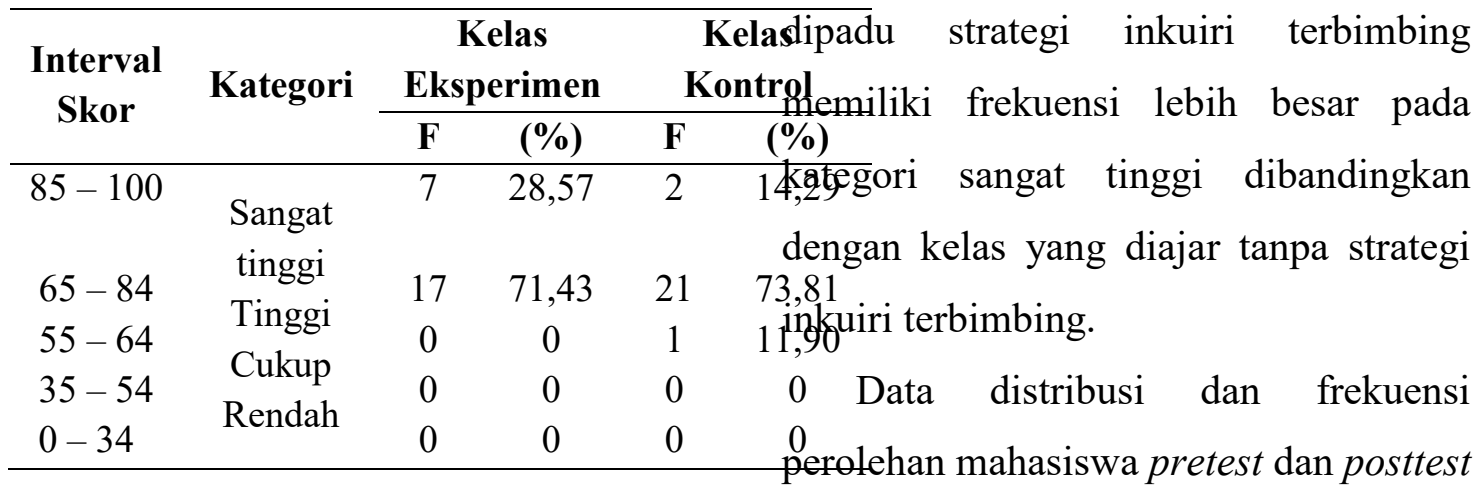


Jurnal Binomial Vol. 3 No. 2 September 2020

baik kelas eksperimen maupun kelas kontrol, diperkuat oleh data distribusi selisih nilai hasil belajar mahasiswa dengan menggunakan persamaan Normalisasi Gain. Selisih nilai tersebut dapat dilihat pada Tabel 5.

Tabel 5 Distribusi Nilai Selisih (Gain Score) Hasil Belajar

\begin{tabular}{cccccc}
\hline \multirow{2}{*}{ Interval Nilai } & \multirow{2}{*}{ Kategori } & \multicolumn{2}{c}{$\begin{array}{c}\text { Kelas } \\
\text { Eksperimen }\end{array}$} & \multicolumn{2}{c}{$\begin{array}{c}\text { Kelas } \\
\text { Kontrol }\end{array}$} \\
\cline { 3 - 6 } & & $\mathbf{F}$ & $\mathbf{( \% )}$ & $\mathbf{F}$ & $\mathbf{( \% )}$ \\
\hline $0 \leq \mathrm{N}<0,3$ & Rendah & 0 & 0 & 0 & 0 \\
$0,3 \leq \mathrm{N}<0,7$ & Sedang & 8 & 33,33 & 11 & 52,38 \\
$0,7 \leq \mathrm{N} \leq 1,0$ & Tinggi & 14 & 67,67 & 13 & 47,62 \\
\hline
\end{tabular}

Tabel 5 memperlihatkan besarnya selisih nilai hasil belajar mahasiswa dengan Normalisasi Gain sebelum dan sesudah diajar materi sistem pernapasan baik kelas eksperimen maupun kelas kontrol. Hasil yang diperoleh pada kelas eksperimen untuk kategori rendah sebanyak $0 \%$, untuk kategori sedang sebanyak 33,33\%, dan pada kategori tinggi sebanyak 67,67\%. Hasil yang diperoleh pada kelas kontrol untuk kategori rendah sebanyak $0 \%$, kategori sedang sebanyak 52,38\%, dan pada kategori tinggi sebanyak 47,62\%. Hasil yang diperoleh membuktikan bahwa hasil belajar mahasiswa kelas eksperimen lebih baik dibandingkan dengan hasil belajar kelas kontrol.

\section{Pembahasan Hasil Penelitian}

1. Aktivitas mahasiswa

Berdasarkan hasil analisis deskriptif menunjukan bahwa aktivitas belajar mahasiswa yang diajarkan dengan penerapan model pembelajaran kooperatif tipe STAD yang dipadu strategi inkuiri terbimbing lebih baik dibandingkan dengan penerapan model pembelajaran kooperatif tipe $S T A D$. Hal ini terlihat dari persentase aktivitas belajar di kelas eksperimen yang berada pada kategori sangat aktif dan kategori aktif lebih tinggi, sedangkan di kelas kontrol masih banyak yang berada pada kategori kurang aktif dan tidak aktif. Hasil tersebut didukung oleh teori Sanjaya (2012) menyatakan bahwa strategi inkuiri dapat meningkatkan aktifitas dalam mencari dan menemukan sendiri jawaban dari permasalahan yang ada. Strategi inkuiri dengan sintaksnya memberikan perhatian besar pada aktivitas aktif mahasiswa, baik fisik maupun mental dalam proses pembelajaran. Hal tersebut juga sejalan hasil penelitian Asminah (2010), yang melaporkan bahwa aktivitas lebih tinggi dengan menggunakan metode inkuiri terbimbing. 
Jurnal Binomial Vol. 3 No. 2 September 2020

Beberapa indikator aktivitas yang diamati seperti membentuk kelompok sesuai arahan dosen, mengumpulkan data melalui kajian literatur, berdiskusi dengan teman kelompok untuk menyelesaikan modul dan melakukan presentasi atau memberikan pertanyaan/tanggapan, menunjukkan bahwa mahasiswa lebih aktif di kelas eksperimen dibandingkan kelas kontrol. Aktivitas mahasiswa di kelas kontrol, cenderung pasif saat berdiskusi kelompok dan melakukan presentasi serta tidak bersemangat saat menyelesaikan modul karena pengumpulan data hanya dilakukan melalui kajian literatur, sehingga mereka merasa bosan dan jenuh selama proses pembelajaran. Hal ini terlihat dari persentase aktivitas mahasiswa pada indikator yang diamati.

Aktivitas mahasiswa di kelas eksperimen dengan penerapan model pembelajaran kooperatif $S T A D$ yang dipadu strategi inkuiri terbimbing menunjukkan mahasiswa lebih aktif, antusias dan bersemangat dalam mengikuti setiap tahapan pembelajaran kooperatif tipe $S T A D$ dipadukan inkuiri terbimbing, seperti pada tahapan pengumpulan data, mahasiswa lebih aktif dan antusias karena tahapan tersebut tidak hanya dilakukan melalui kajian literatur dari berbagai sumber, tetapi juga dilakukan melalui praktikum (eksperimen), sehingga mereka terlibat langsung dalam mencari dan menemukan pengetahuan. Hal tesebut berdampak pada peningkatan tiap tahapan pembelajaran setiap pertemuan.

Perbedaan antara aktivitas mahasiswa di kelas eksperimen yang dibelajarkan dengan penerapan model pembelajaran kooperatif tipe $S T A D$ yang dipadu strategi inkuiri terbimbing inkuiri dengan kelas kontrol yang dibelajarkan dengan penerapan model pembelajaran kooperatif tipe $S T A D$, disebabkan karena tahapan pembelajaran yang diamati berbeda. Pada kelas eksperimen, pembelajaran dilakukan berdasarkan tahapan-tahapan kooperatif tipe STAD dipadukan inkuiri terbimbing yaitu merumuskan masalah, merumuskan hipotesis, melakukan percobaan, mengumpulkan data, merumuskan kesimpulan, berdiskusi kelompok dan mengkomunikasikan hasil penelitian kepada teman-temannya. Aktivitasaktivitas ilmiah inilah yang menjadikan keterlibatan aktif mahasiswa pada saat pembelajaran menjadi lebih banyak jika dibandingkan pembelajaran dengan 
Jurnal Binomial Vol. 3 No. 2 September 2020

menggunakan model pembelajan kooperatif tipe $S T A D$.

Menurut Slavin (2009), tujuan dibentuknya kelompok kooperatif adalah untuk memberikan kesempatan kepada mahasiswa agar dapat terlibat secara aktif dalam proses berpikir selama kegiatan belajar mengajar. Sementara Gulo (2002), menyatakan bahwa sasaran utama kegiatan pembelajaran inkuiri adalah mahasiswa terlibat secara maksimal yang melibatkan kegiatan mental intelektual dan sosial emosional, serta mengembangkan sikap percaya diri tentang apa yang ditemukan selama proses inkuiri. Jadi, penerapan model pembelajaran kooperatif tipe STAD yang dipadu strategi inkuiri terbimbing memberikan kesempatan kepada mahasiswa untuk bekerja mencari dan menemukan jawaban yang sebenarnya atas jawaban sementara yang dikemukakan oleh mahasiswa sendiri melalui pembelajaran kooperatif, sehingga rasa ingin tahu siswa semakin berkembang.

Hal senada dikemukakan Rohmatika (2013), bahwa inkuiri terbimbing dipadu kooperatif mampu meningkatkan rasa ingin tahu dan rasa percaya diri. Rasa ingin tahu meningkat melalui proses merumuskan pertanyaan, penyelidikan, dan pengumpulan data (eksperimen), sedangkan rasa percaya diri berkembang ketika mengkomunikasikan hasil temuannya. Selain itu, adanya pemberian penghargaan pada kelompok terbaik juga mampu meningkatkan minat belajar mahasiswa untuk lebih meningkatkan aktivitas.

Hal serupa juga diungkapkan Nurhidayati (2012) dalam penelitiannya, melaporkan bahwa terdapat pengaruh metode pembelajaran terhadap aktivitas belajar mahasiswa. Kelompok yang dibelajarkan dengan metode integrasi $S T A D$-inkuiri terbimbing memiliki aktivitas belajar lebih tinggi dibandingkan dengan kelompok yang dibelajarkan dengan metode STAD, inkuiri terbimbing dan konvensional. Begitu pula penelitian Afiah (2010), mengungkapkan bahwa melalui model kooperatif dengan metode inkuiri terbimbing dapat meningkatkan aktivitas belajar.

Berdasarkan penjelasan-penjelasan di atas, menunjukkan bahwa penerapan model pembelajaran kooperatif tipe STAD yang dipadu inkuiri terbimbing memberikan peluang besar kepada siswa untuk aktif atau terlibat langsung selama 
Jurnal Binomial Vol. 3 No. 2 September 2020

proses pembelajaran, sehingga untuk saling bekerjasama agar tercipta pembelajaran mencapai tujuan yang variasi pembelajaran yang menarik.

ditetapkan dan hasil belajar mencapai hasil yang maksimal.

2. Hasil Belajar mahasiswa

Berdasarkan hasil penelitian, masih banyak mahasiswa yang berada pada kategori sangat rendah dan rendah sebelum diberikan perlakuan, hal ini disebabkan karena kurangnya pengetahuan yang mereka miliki mengenai materi sistem pernapasan. Setelah dibelajarkan dengan penerapan model pembelajaran kooperatif tipe STAD yang dipadu strategi inkuiri terbimbing hasil belajar yang mereka peroleh meningkat, hal ini dibuktikan dengan hasil belajar berada pada kategori tinggi dan sangat tinggi.

Model pembelajaran kooperatif tipe STAD merupakan tipe pembelajaran kooperatif yang sederhana dimana mereka bekerjasama dalam satu kelompok untuk memecahkan suatu masalah. Model pembelajaran kooperatif tipe STAD merupakan model pembelajaran yang paling sering digunakan oleh dosen dalam pembelajaran, sehingga dibutuhkan penggabungan antara strategi yang sesuai 
Jurnal Binomial Vol. 3 No. 2 September 2020

Temuan penelitian ini menunjukkan bahwa terdapat perbedaan yang signifikan terhadap hasil belajar antara kelas yang dibelajarkan menggunakan model pembelajaran kooperatif tipe STAD yang dipadu strategi inkuiri terbimbing dan kelas yang menggunakan model pembelajaran kooperatif tipe STAD. Hal ini mengindikasikan bahwa proses pembelajaran yang baik dapat memberikan konstribusi positif bagi mahasiswa, sehingga mereka semakin menyadari pentingnya belajar biologi khususnya pokok bahasan sistem pernapasan dan mereka mampu mengkonstruksi pengetahuannya. Hal ini didukung oleh teori konstruktivisme Vigotzky, yang menganggap bahwa mahasiswa lebih mudah menemukan dan memahami konsep-konsep yang sulit jika mereka saling mendiskusikan masalah tersebut dengan temannya. Hasil penelitian tersebut sejalan dengan penelitian Budiarti (2012), yang menyimpulkan bahwa rata-rata hasil belajar kelompok STAD berbasis inkuiri terbimbing lebih baik daripada kelompok STAD tanpa inkuiri terbimbing. Begitu pula hasil penelitian Nurhidayati (2012), bahwa kelompok yang dibelajarkan dengan metode integrasi STAD-inkuiri terbimbing memiliki hasil belajar kognitif lebih tinggi dibandingkan dengan kelompok yang dibelajarkan dengan metode $S T A D$, inkuiri terbimbing dan konvensional.

Berdasarkan hasil analisis jalur menunjukkan bahwa model pembelajaran kooperatif tipe STAD yang dipadu strategi inkuiri terbimbing berpengaruh langsung sebesar $26 \%$ terhadap hasil belajar mahasiswa, sedangkan pengaruh tidak langsung model pembelajaran kooperatif tipe STAD yang dipadu strategi inkuiri terbimbing terhadap hasil belajar mahasiswa sebesar 34\%. Hal tersebut mengindikasikan bahwa nilai koefisien jalur pengaruh tidak langsung lebih besar daripada pengaruh langsung. Berarti ada $66 \%$ faktor lain diluar diluar model dan aktivitas yang mempengaruhi hasil belajar mahasiswa. Sejalan dengan hal tersebut Slameto (2003), menyatakan bahwa hasil belajar dipengaruhi oleh beberapa faktor, yakni faktor dari dalam (internal) dan faktor dari luar (eksternal) Faktor internal adalah faktor jasmaniah, psikologis, dan faktor kelelahan (misalnya, intelegensi, perhatian, minat, bakat, motivasi, kematangan, kesiapan), sedangkan yang termasuk faktor eksternal adalah faktor keluarga, faktor 
Jurnal Binomial Vol. 3 No. 2 September 2020

sekolah, dan faktor masyarakat (misalnya

dosen, kurikulum, dan model pembelajaran).

Isjoni (2009), menyatakan bahwa cara belajar kelompok adalah suatu cara pendekatan/strategi yang khusus dirancang untuk memberi dorongan kepada peserta didik untuk bekerja sama selama pembelajaran, yang tentunya dapat meningkatkan pemahaman. Hal inilah yang juga terjadi pada kelas eksperimen. Siswa dimotivasi agar mau bekerjasama selama pembelajaran. Hal inilah yang memunculkan interaksi yang kuat antara mahasiswa dengan mahasiswa dan mahasiswa dengan dosen sebagai pembimbing dalam proses pembelajaran, yang akhirnya dapat meningkatkan hasil belajar mereka, khususnya pada pokok bahasan sistem pernapasan.

Alasan mengapa nilai belajar mahasiswa kelas eksperimen lebih baik dibandingkan dengan nilai belajar kelas kontrol, padahal dengan penerapan model pembelajaran yang sama, hal ini disebabkan karena penerapan kooperatif tipe $S T A D$ yang dipadu strategi inkuiri terbimbing merupakan alternatif pembelajaran biologi yang berbasis konstruktivis dan kolaboratif.
Konstruktivis membawa siswa menuju paradigma pembelajaran biologi sesungguhnya yaitu mengkonstruk pengetahuan secara mandiri, tidak sebatas menghafal pengetahuan. Kolaboratif melatih siswa menumbuhkan iklim kooperatif yaitu perkembangan sosial kerjasama, motivasi, kompetisi, dan penyamarataan kemampuan (Prayitno, 2010). Seperti yang diungkapkan dari hasil penelitian Mumpuni (2012) bahwa strategi pembelajaran INSTAD (inkuiri dipadu dengan kooperatif STAD) lebih dapat meningkatkan hasil belajar kognitif dibanding strategi pembelajaran konvensional.

Ada beberapa kendala yang peneliti alami selama pelaksanaan penelitian ini seperti, (1) penelitian ini memadukan model dan strategi pembelajaran, sehingga memerlukan waktu yang panjang, untuk itu peneliti harus pandai menyesuaikan dengan waktu yang telah ditentukan, (2) saat praktikum dan diskusi berlangsung, terkadang terjadi kegaduhan-kegaduhan diantara siswa dimana ada siswa yang mengambil kesempatan untuk bermain-main dalam pelaksanaan diskusi, untuk itu peneliti dibantu observer berusaha 
Jurnal Binomial Vol. 3 No. 2 September 2020

mengkondusifkan mahasiswa dengan membimbing dan memberi pengarahan.

Terlepas dari kendala-kendala yang dialami selama penelitian, hasil penelitian ini dapat membuktikan bahwa penerapan model pembelajaran kooperatif tipe $S T A D$ yang dipadu inkuiri terbimbing dianggap lebih baik dan lebih mampu meningkatkan hasil belajar jika dibandingkan dengan model pembelajaran kooperatif tipe $S T A D$.

\section{PENUTUP}

\section{Kesimpulan}

Berdasarkan hasil penelitian dan pembahasan dapat disimpulkan beberapa hal sebagai berikut.

1. Aktivitas mahasiswa STKIP PI yang diajar dengan penerapan model pembelajaran kooperatif tipe $S T A D$ yang dipadu strategi inkuiri terbimbing berada pada kategori sangat aktif.

2. Hasil belajar mahasiswa STKIP PI yang diajar dengan penerapan model pembelajaran kooperatif tipe $S T A D$ yang dipadu strategi inkuiri terbimbing berada pada kategori tinggi.

3. Ada pengaruh signifikan penerapan model pembelajaran kooperatif tipe
STAD yang dipadu strategi inkuiri terbimbing terhadap hasil belajar sistem pernapasan pada mahasiswa STKIP PI.

4. Ada pengaruh tidak langsung penerapan pembelajaran kooperatif tipe $S T A D$ yang dipadu strategi inkuiri terbimbing terhadap hasil belajar sistem pernapasan pada mahasiswa STKIP PI melalui aktivitas.

\section{Saran}

1. Diharapkan kepada dosen mata kuliah Biologi lainnya untuk menerapkan model pembelajaran kooperatif tipe STAD yang dipadu strategi inkuiri terbimbing karena terbukti mampu meningkatkan aktivitas dan hasil belajar mahasiswa.

2. Penerapan model pembelajaran kooperatif tipe STAD yang dipadu strategi inkuiri terbimbing hendaknya disesuaikan dengan materi pelajaran yang diajarkan dan mengandung unsur eksperimen yang menantang dan memungkinkan adanya penyelidikan, serta memberi peluang bekerja kolaboratif dalam memecahkan masalah.

3. Kepada peneliti selanjutnya yang ingin menerapkan model pembelajaran 
kooperatif tipe STAD yang dipadu strategi inkuiri terbimbing diharapkan dapat lebih mengembangkan sintaks dari model pembelajaran tersebut dengan menyesuaikan kondisi mahasiswa yang akan diteliti, atau dapat pula mengembangkan penelitian ini dengan menerapkan model pembelajaran kooperatif tipe $S T A D$ yang dipadu dengan strategi lain, yang dianggap lebih baik.

\section{DAFTAR PUSTAKA}

Afiah, N. 2010. Penerapan Model Pembelajaran Kooperatif dengan Metode Inkuiri Terbimbing pada Mata Pelajaran Fisika Kelas XI IPA di SMA Negeri 2 Makassar. Tesis tidak diterbitkan. Universitas Negeri Makassar.

Ambarsari, W. 2012. Penerapan Pembelajaran Inkuiri Terbimbing terhadap Keterampilan Proses Sains Dasar pada Pelajaran Biologi Kelas VII SMP Negeri 7 Surakarta. Jurnal Pendidikan Biologi, (online), Vol. 5, No. 1, hlm. 81-95, (http://jurnal.fkip.uns.ac.id, Diakses 12 Oktober 2013).

Asminah, D. R (2010). Pembelajaran Fisika dengan Metode Inkuiri Terbimbing dan Inkuiri Training Ditinjau dari Kemampuan Awal dan Aktivitas Siswa. Tesis. Universitas Sebelas Maret.

Astrawan. 2013. Pengaruh Model Pembelajaran Kooperatif Tipe Student Team Achievement Division terhadap Motivasi Belajar dan Hasil Belajar
IPA. e-Journal. Vol. 3. Program Pascasarjana Universitas Pendidikan Ganesha Jurusan Pendidikan Dasar.

Budiada, I. $\quad$ P. 2011. Pengaruh Penerapan Model Pembela jaran Inkuiri Terbimbing Berbasis Asesmen Portofolio Terhada p Hasil Belajar Kimia Siswa Kelas X Ditinjau dari Adversity Quotient. Jurnal Penelitian, (online), Vol. 2, No.1, (http://pasca.undiksha.ac.id, Diakses 01 Juni 2014).

Budiarti, S. 2012. Penerapan Model Pembelajaran Student Teams Achievement Division Berbasis Inkuiri Terbimbing Untuk Pembelajaran Kimia Materi Pokok Koloid. (Online), (http://lib.unnes.ac.id. , Diakses tanggal 30 Mei 2014)

Dewi, L. N. 2013. Pengaruh Model Pembelajaran Inkuiri Terbimbing terhadap Sikap Ilmiah dan Hasil Belajar IPA. e-Journal. Vol. 3. Program Pascasarjana Universitas Pendidikan Ganesha Jurusan Pendidikan Dasar.

Gulo, W. 2002. Strategi Belajar Mengajar. PT Gramedia Widiasarana: Jakarta.

Hapsari, D. P. 2012. Pengaruh Model Inkuiri Terbimbing dengan Diagram $V$ (Vee) dalam Pembelajaran Biologi terhadap Kemampuan Berpikir Kritis dan Hasil Belajar Siswa. Jurnal Pendidikan Biologi, (online), Vol. 4, No. 3, hlm. 16-28, (http://jurnal.fkip.uns.ac.id, Diakses 12 Oktober 2013).

Isjoni. 2009. Cooperative Learning. Alfabeta: Bandung.

Mumpuni, K. E. 2012. Pengaruh Strategi Pembelajaran INSTAD terhadap Metakognisi dan Hasil Belajar 
Kognitif Biologi Siswa SMA. Jurnal Pendidikan Biologi, (online), Vol. 1, No. 1, hlm. 28-35, (http://jurnal.fkip.uns.ac.id, Diakses 01 juli 2014).

Nurhayati B. 2011. Strategi Belajar Mengajar. Badan Penerbit UNM: Makassar.

Nurhidayati, S. 2012. Pengaruh Metode STAD dan Inkuiri Terbimbing terhadap Aktivitas dan Hasil Belajar Biologi Siswa Kelas X SMA Laboratorium Universitas Negeri Malang. (Online), (http://pasca.um.ac.id),__Diakses tanggal 30 Mei 2014)

Prayitno, B. A. 2010. Potensi Pembelajaran Biologi Inkuiri Dipadu Kooperatif dalam Pemberdayaan Berpikir dan Keterampilan Proses pada Siswa Under Achievment. Proceeding Seminar Nasional Optimalisasi Sains untuk Memberdayakan Manusia, hlm. 677689.Surabaya: UNESA.

Rustam. 2010. Model-Model Pembelajaran. PT Rajagrafindo Persada: Jakarta.

Rokhmatika, S. 2012. Pengaruh Model Inkuiri Terbimbing Dipadu Kooperatif Jigsaw terhadap Keterampilan Proses Sains Ditinjau dari Kemampuan Akademik. Jurnal Pendidikan Biologi, (online), Vol. 4, No.2, hlm. 72-83, (http://jurnal.fkip.uns.ac.id, Diakses 12 Oktober 2013).

Sanjaya, W. 2012. Strategi Pembelajaran Berorientasi Standar Proses Pendidikan. Kencana: Jakarta.

Slameto. 2003. Belajar dan FaktorFaktor yang Memengaruhinya. Rineka Cipta: Jakarta.
Slavin, R. 2009. Cooperative Learning: Teori, Riset, and Praktis (Terjemahan dari Cooperative Learning: Theory, Research, dan Practice. Terjemahan oleh Yusron, Nurilita. 2010. Nusa Media: Bandung. 